\title{
Kebijakan Pemerintah dalam Pengelolaan Sampah Domestik
}

\author{
Government Policy in Domestic Waste Management
}

\author{
Surahma Asti Mulasari* Adi Heru Husodo** Noeng Muhadjir***
}

*Fakultas Kesehatan Masyarakat Universitas Ahmad Dahlan, **Jurusan Ilmu Kedokteran Klinik Fakultas Kedokteran Universitas Gadjah Mada,*** Universitas Negeri Yogyakarta

\begin{abstract}
Abstrak
Sampah berpotensi menciptakan masalah kesehatan lingkungan. Pemerintah mengupayakan berbagai kebijakan pengelolaan sampah seperti pelayanan sampah dan memberdayakan masyarakat untuk mengelola sampah secara mandiri. Tujuan penelitian adalah untuk mengetahui kebijakan pemerintah dalam mengelola sampah domestik di Daerah Istimewa Yogyakarta (DIY), perubahan kualitas lingkungan dan masyarakat akibat kebijakan pengelolaan sampah, dan untuk mengetahui metode pemantauan dan pengelolaan sampah yang ada di DIY. Jenis penelitian ini adalah kualitatif dengan rancangan studi kasus. Fenomena yang menjadi studi dalam penelitian ini adalah kebijakan pengelolaan sampah di DIY. Permasalahan sampah yang ada di DIY adalah cakupan pelayanan pemerintah kabupaten yang masih sangat rendah, kecuali Kota Yogyakarta (90\%). Sampah terangkut ke tempat pembuangan akhir masih rendah dibandingkan volume sampah yang dihasilkan. Kebijakan untuk pengelolaan sampah adalah di seluruh kabupaten/kota DIY telah terbentuk badan/unit yang bertanggung jawab mengelola sampah. Perubahan kualitas lingkungan dan masyarakat adalah lingkungan dan jalan menjadi bersih, asri, dan nyaman. Metode pemantauan dan evaluasi kebijakan pengelolaan sampah di DIY belum dituangkan dalam prosedur baku. Permasalahan sampah sudah menjadi perhatian bagi pemerintah daerah DIY. Kebijakan telah didukung dengan program layanan, proyek, regulasi, dan insentif khusus untuk pengelolaan sampah.
\end{abstract}

Kata kunci: Kebijakan, pemerintah daerah, sampah

\section{Abstract}

Waste had great potential in creating environmental health issues. The government had tried various ways of waste management policy such as waste management services and people empowerment to manage their waste independently. The objectives of this study is to observe the problem of garbage in the Daerah Istimewa Yogyakarta (DIY), the Government's policy in managing domestic waste in DIY, the changes in environmental quality and community impact of the waste management, and the methods of monitoring and managing waste in DIY. This research was a qualitative case study design. The phenomenon in this research was the waste management policy in DIY. Waste problem in the province DIY was the district service coverage which was still very low, except for the city of Yogyakarta $(90 \%)$. The waste transported to landfill was still low compared to the volume of waste generated. The policy in DIY for waste management was that in all districts/cities in DIY there had been units formed, responsible for managing waste. The changes in the quality of environment and community were that the environment and roads are getting clean, beautiful, and comfortable. The methods for monitoring and evaluation of waste management policy in the province had not been set forth in the standard procedure. Waste problem had been a concern for local government of DIY. The policy had been supported by the service program, project, regulatory, and special incentives for waste management.

Keywords: Policy, local government, waste

\section{Pendahuluan}

Sampah kota diartikan sebagai sampah yang dibuang oleh masyarakat kota. Permasalahan sampah kota adalah volume sampah besar dan melebihi daya tampung tempat pembuangan akhir (TPA). ${ }^{1}$ Lahan TPA semakin sempit, faktor jarak mengakibatkan mengangkut sampah kurang efektif, teknologi pengolahan sampah tidak optimal, terbatasnya tempat penampungan sampah sementara (TPS), kurangnya sosialisasi dan dukungan pemerintah mengenai pengelolaan sampah, minimnya edukasi dan manajemen diri mengenai pengeolahan sampah, dan manajemen

Alamat Korespondensi: Surahma Asti Mulasari, FKM Universitas Ahmad Dahlan, Jl. Prof. Dr. Soepomo S.H. Janturan Warungboto Yogyakarta 55164, Hp.08164222647, e-mail: rahmasti_fkmuad@yahoo.com 
sampah tidak efektif. ${ }^{2}$

Sampah berdampak pada kesehatan, lingkungan dan sosial ekonomi. ${ }^{3}$ Sampah menjadi tempat pembiakan lalat dan disenangi tikus sehingga mendorong penularan infeksi. Sampah menurunkan kualitas lingkungan, estetika terganggu karena bau dan berserakan. ${ }^{4}$ Pembuangan sampah ke badan air mengakibatkan banjir dan meningkatkan biaya pengelolaan air. Sampah berdampak pada perkembangan pariwisata. ${ }^{3}$ Persoalan sampah dapat menghambat perkembangan otonomi daerah dan mengurangi arus investor. ${ }^{5}$

Pengelolaan sampah perkotaan dilakukan dengan dua sistem, yaitu sentralisasi dan desentralisasi. ${ }^{6}$ Pengelolaan sampah Daerah Istimewa Yogyakarta (DIY) ditangani sebagian besar oleh pemerintah secara sentralisasi. Pengelolaan tersebut mulai dari penarikan retribusi, pengumpulan dari sumber, pengumpulan di TPS, dan pengakutan ke TPA.

Pengolahan sampah di Jakarta masih mengandalkan peran pemerintah. Petugas kebersihan mengambil sampah dari penduduk dan membawa sampah ke TPS untuk diangkut ke TPA oleh dinas kebersihan. Persentasi masyarakat yang dilayani di Jakarta masih sangat tinggi, berarti peran serta masyarakat masih rendah. Di Jakarta mulai dilakukan pemberdayaan masyarakat dalam mengelola sampah untuk mengatasi sampah. ${ }^{7}$ Kota Surabaya menghasilkan sampah 2.177 ton per hari, yang masuk TPA 1.480 ton per hari. Lainnya dikomposkan di sepuluh sentra pengomposan komunal milik Dinas Kebersihan dan Pertanaman (DKP), 13 kelurahan pengomposan rumah tangga, dan dibakar dalam sepuluh unit insenerator mini yang tersebar di wilayah kota. Pemerintah Daerah Surabaya melibatkan pemerintah, swasta, dan masyarakat dalam mengelola sampah. ${ }^{8} \mathrm{Di}$ Kota Bandung, tanggung jawab pengelolaan sampah dibagi menjadi dua, yaitu pengangkutan dari rumah ke TPS menjadi tanggung jawab masyarakat sedangkan dari TPS ke TPA menjadi tanggung jawab pemerintah. Pengelolaan di Bandung belum baik ditandai dengan banyaknya sampah yang tidak terangkut dari TPS dan yang menumpuk di beberapa bagian kota. Pemberdayaan masyarakat mulai digalakkan untuk mengatasi sampah. ${ }^{9}$

Kota Yogyakarta, Sleman, dan Bantul menggunakan TPA Piyungan. TPA Piyungan berada di Bantul, tetapi justru Bantul memberikan kontribusi sampah paling rendah dibandingkan dengan Kota Yogyakarta dan Sleman karena sebagian Bantul merupakan perdesaan dan memiliki lahan kosong yang luas. Secara garis besar, pemerintah DIY belum mengalami kendala pengelolaan sampah, akan tetapi perlu dikaji lebih jauh tentang kemungkinan timbulnya permasalahan sampah dikemudian hari.

Tujuan dari penelitian ini adalah untuk mengetahui perbedaan kebijakan pemerintah dalam pengelolaan sampah domestik yang dilakukan lima kabupaten/kota di DIY, mengetahui perubahan kualitas lingkungan dan masyarakat akibat kebijakan pengelolaan sampah tersebut, dan untuk mengetahui metode pemantauan dan pengelolaan sampah yang ada di lima kabupaten/kota di DIY.

\section{Metode}

Jenis penelitian ini adalah kualitatif dengan rancangan studi kasus. Penelitian ini memberi pengetahuan terjadinya fenomena pada individual, organisasi, sosial dan politik. Konsep triangulasi dipergunakan untuk menanggapi secara positif kelemahan yang ada, menggunakan metode dan sumber data secara berganda.

Lokasi penelitian di DIY meliputi satu Kotamadya Yogyakarta, empat kabupaten yaitu Bantul, Sleman, Kulon Progo, dan Gunung Kidul. Responden penelitian ini adalah staf Badan Lingkungan Hidup (BLH) Kota Yogyakarta, BLH Kabupaten Bantul, Dinas Pekerjaan Umum (DPU) Bantul, KLH Sleman dan Kulon Progo, DPU Kulon Progo, Dinas Pekerjaan Umum Unit Pelaksana Teknis (DPU UPT) Kebersihan dan Pertamanan Gunung Kidul, masyarakat pengelola sampah mandiri dari Sukunan Sleman, Kelurahan Bener Yogyakarta, Badekan Bantul, masyarakat umum di Kulon Progo dan Gunung Kidul.

Analisis data dilakukan dengan mendeskripsikan dan menyajikannya dalam bentuk teknik penjelasan (explanation-building). Semua sumber diperiksa dan dievaluasi bersama sehingga merupakan gabungan informasi dari berbagai jenis bukti-dokumen, peralatan, wawancara dan observasi. Analisis data dilakukan dengan analisis transkrip. ${ }^{10}$

\section{Hasil}

Sampah di DIY belum menjadi prioritas seperti halnya sampah di beberapa kota besar. Permasalahan sampah yang ada di kabupaten/kota di DIY berdasarkan hasil studi pendahuluan (Tabel 1). Cakupan pelayanan terbaik ada di Kota Yogyakarta yaitu dapat melayani 90 persen daerah. Demikian halnya untuk sampah yang terangkut ke TPA paling banyak adalah Kota Yogyakarta (34,89\%), sedangkan terendah berada di Kabupaten Bantul $(1,91 \%)$.

Dari Tabel 2, dapat dilihat bahwa badan pelaksana untuk pengelolaan sampah yang dilakukan di lima kabupaten/kota di DIY yaitu Kota Yogyakarta, Kabupaten Bantul, Kabupaten Sleman, Kabupaten Kulon Progo, dan kabupaten Gunung Kidul. Regulasi sebagai dasar hukum pelaksanaan pengelolaan sampah bervariasi, tetapi semua berproses berdasarkan aturan yang ada, baik itu aturan yang bersifat nasional ataupun lokal daerah. Program yang dimaksud dalam penelitian ini adalah kegiatan pelayanan yang dilakukan oleh Pemerintah daerah untuk 
Tabel 1. Permasalahan Sampah

\begin{tabular}{|c|c|c|c|c|c|c|c|}
\hline Kabupaten & Jumlah Penduduk & $\begin{array}{l}\text { Volume Sampah } \\
\left( \pm m^{3} / \text { hari }\right)\end{array}$ & $\begin{array}{c}\text { Volume Sampah } \\
\text { Berdasarkan } \\
\text { Jumlah Penduduk } \\
\left( \pm \mathrm{m}^{3} / \text { hari }\right)\end{array}$ & $\begin{array}{c}\text { Penduduk Terlayani } \\
(\%)\end{array}$ & $\begin{array}{l}\text { Sampah Terangkut } \\
\quad\left( \pm \mathrm{m}^{3} / \text { hari }\right)\end{array}$ & $\begin{array}{c}\text { Sampah Terangkut } \\
(\%)\end{array}$ & TPSA \\
\hline Yogyakarta & 541.250 & 320 & 487,125 & 90 & 170 & 34,89 & Piyungan \\
\hline Sleman & 850.176 & 2.917 .75 & $2.125,44$ & 9,6 & 280 & 13,17 & Piyungan \\
\hline Bantul & 1.020 .363 & $2.550,91$ & $2.550,9075$ & 1,9 & 48,73 & 1,91 & Piyungan \\
\hline Kulon Progo & 388.755 & 70 & 971,8875 & 7,2 & 70 & 7,20 & Banyuroto \\
\hline Gunung Kidul & 424.348 & 334,17 & $1.060,87$ & 17 & 57 & 5,37 & Baleharjo \\
\hline
\end{tabular}

Keterangan : Diselaraskan dengan teori bahwa sampah yang dihasilkan per orang adalah 2,5 liter/org/hari

Tabel 2. Kebijakan Pengelolaan Sampah

\begin{tabular}{|c|c|c|c|c|c|}
\hline Kabupaten/Kota & Badan Pelaksana & Regulasi & Program Kebijakan & Proyek & Insentif \\
\hline Yogyakarta & $\begin{array}{l}\text { Badan } \\
\text { Lingkungan } \\
\text { Hidup }\end{array}$ & $\begin{array}{l}\text { UU No.18 Tahun } 2008 \\
\text { Perda Kota Yogyakarta } \\
\text { No.18 Tahun } 2002\end{array}$ & $\begin{array}{l}\text { Pengumpulan dan } \\
\text { pengangkutan sampah }\end{array}$ & $\begin{array}{l}\text { Komposting, } \\
\text { daur ulang plastik, } \\
\text { bank sampah, } \\
\text { faskel, } \\
\text { jejaring pengepul } \\
\text { Kota Yogyakarta }\end{array}$ & $\begin{array}{l}\text { Dana stimulan } 2 \text { juta, } \\
\text { Lomba dengan pemenang } \\
\text { Rp15 juta, tanaman, dan } \\
\text { mesin pencacah, } \\
\text { Honor sosialisasi } \\
\text { Pembagian bak takakura } \\
\text { ( } 14.750 \text { keranjang takaku- } \\
\text { ra untuk } 14 \text { kelurahan) }\end{array}$ \\
\hline Bantul & $\begin{array}{l}\text { Badan } \\
\text { Lingkungan } \\
\text { Hidup, } \\
\text { Dinas } \\
\text { Pekerjaan } \\
\text { Umum }\end{array}$ & $\begin{array}{l}\text { UU No. } 18 \text { Tahun } 2008 \text {, } \\
\text { Permendagri No.33 } \\
\text { Tahun 2010, } \\
\text { Perda Kabupaten Bantul } \\
\text { No.15 Tahun } 2011\end{array}$ & $\begin{array}{l}\text { Pengumpulan dan } \\
\text { pengangkutan sampah, } \\
\text { jejaring pengelolahan } \\
\text { sampah mandiri }\end{array}$ & $\begin{array}{l}\text { Pengomposan, } \\
\text { bank sampah, 3R, } \\
\text { jejaring pengelola sampah } \\
\text { mandiri }\end{array}$ & $\begin{array}{l}\text { Gerobak, tong sampah, } \\
\text { komposter, mesin jahit, } \\
\text { mesin pencacah sampah } \\
\text { organik, dan mesin pen- } \\
\text { cacah sampah plastik, } \\
\text { mengikutsertakan komu- } \\
\text { nitas pada kompetisi } \\
\text { tingkat nasional }\end{array}$ \\
\hline Sleman & $\mathrm{KLH}$ & $\begin{array}{l}\text { Perda Kabupaten Sleman } \\
\text { No } 14 \text { Tahun 2007, } \\
\text { Perda Kabupaten Sleman } \\
\text { No. } 13 \text { Tahun } 2011\end{array}$ & $\begin{array}{l}\text { Pengumpulan dan } \\
\text { pengangkutan sampah }\end{array}$ & $\begin{array}{l}\text { Pengomposan, } \\
\text { daur ulang, dan } \\
\text { daerah swakelola sampah }\end{array}$ & $\begin{array}{l}\text { Reward perlombaan, } \\
\text { keringanan retribusi } \\
\text { untuk pengurangan } \\
\text { residu, dan B3 rumah } \\
\text { tangga }\end{array}$ \\
\hline Kulon Progo & $\begin{array}{l}\text { Dinas PU oleh } \\
\text { UPTD kebersihan } \\
\text { dan pertanaman, } \\
\text { Dinas KLH }\end{array}$ & $\begin{array}{l}\text { UU No. } 18 \text { Tahun } 2008 \text {, } \\
\text { UU No. } 32 \text { Tahun } 2009 \text {, } \\
\text { Perda Kabupaten } \\
\text { Daerah Tingkat II } \\
\text { No.08 tahun } 1991 \text {, } \\
\text { Peraturan Bupati } \\
\text { Kulon Progo No.17 } \\
\text { Tahun 2005, Instruksi } \\
\text { Bupati KP No. } 03 \\
\text { Tahun } 2010\end{array}$ & $\begin{array}{l}\text { Pengumpulan dan } \\
\text { pengangkutan sampah, } \\
\text { mobil hijau }\end{array}$ & $\begin{array}{l}\text { Mobil Hijau KLH, 3R, } \\
\text { dan kegiatan pemilahan } \\
\text { sampah }\end{array}$ & $\begin{array}{l}\text { Penghargaan terhadap } \\
\text { program pengelolaan } \\
\text { sampah }\end{array}$ \\
\hline Gunung Kidul & $\begin{array}{l}\text { DPU UPT } \\
\text { Kebersihan dan } \\
\text { Pertamanan }\end{array}$ & UU No.18 Tahun 2008 & $\begin{array}{l}\text { Pengumpulan dan } \\
\text { pengangkutan sampah }\end{array}$ & $\begin{array}{l}\text { Program peran serta } \\
\text { masyarakat, yaitu } \\
\text { penyuluhan, pembinaan, } \\
\text { pelatihan, penyediaan } \\
\text { sarana prasarana, gotong } \\
\text { royong, dan 3R }\end{array}$ & $\begin{array}{l}\text { Pemberian sarana dan } \\
\text { prasarana }\end{array}$ \\
\hline
\end{tabular}

pengelolaan sampah.

Dampak kebijakan pengelolaan sampah pada perubahan kualitas lingkungan dan kesehatan masyarakat di lima kabupaten/kota di DIY relatif sama, yaitu bersih, asri, dan nyaman. Pemerintah lewat kebijakannya mendorong keterlibatan aktif masyarakat dalam mengelola sampah. Hal tersebut diharapkan dapat mengubah perilaku masyarakat sehingga daya dukung lingkungan dapat terus dirasakan oleh masyarakat. Keuntungan ekonomi diperoleh masyarakat ketika mau mengelola sampah secara mandiri.

Pemantauan yang dilakukan berbeda antara lima daerah kabupaten/kota di DIY. Pemantauan kegiatan dilakukan untuk tujuan yang sama yaitu memastikan kebijakan berjalan dengan baik, akuntabilitas, dan transparansi. Hal tersebut dilakukan sebagai bentuk tanggung jawab pemerintah terhadap masyaraka (Tabel 3). 
Tabel 3. Bukti Pelaporan Kebijakan Pengelolaan Sampah

\begin{tabular}{ll}
\hline Kabupaten/Kota & \multicolumn{1}{c}{ Jenis Pemantauan } \\
\hline Yogyakarta & $\begin{array}{l}\text { Pembuatan laporan periodik volume sampah harian } \\
\text { Pembuatan profil pengelolaan sampah kota Yogyakarta } \\
\text { Pembuatan profil pengelolaan sampah rumah tangga } \\
\text { dengan memilah dan mengolah sampah 3R }\end{array}$ \\
Bantul & Laporan periodik per bulan sampah harian \\
& Dokumen/data sekunder Program Pengelolaan Sampah \\
& KLH Bantul dan DPU Bantul, dan Data Pengelolan TPST \\
& Piyungan \\
& Pembuatan profil pengelolaan persampahan \\
Sleman & Data sekunder pengelolaan persampahan dari DPUP \\
& Sleman \\
Kulon Progo & Data sekunder KLH dan PU tentang persampahan \\
& Ada review rencana strategis (renstra) KLH Kabupaten \\
& Kulon Progo \\
Data Sekunder DPU UPT Kebersihan dan Pertamanan \\
Gunung Kidul & Dokumen Masterplan persampahan dan DED TPA Gunung \\
& Kidul
\end{tabular}

\section{Pembahasan}

\section{Analisis Profil Persampahan di DIY}

TPA terbesar di DIY adalah TPA Piyungan yang setiap harinya dijadikan tempat akhir puluhan truk sampah yang beroperasi di tiga daerah (Kota Yogyakarta, Sleman, dan Bantul). Pengoperasian TPA Piyungan di bawah pengawasan Sekretariat Bersama Yogyakarta, Sleman, dan Bantul (Sekber Kartamantul). Sampah yang dibuang ke TPA lebih sedikit secara persentase bila dibandingkan jumlah sampah yang dihasilkan penduduk di masing-masing kabupaten kota di DIY. Hal tersebut dikarenakan keadaan geografis mereka yang masih sebagian berupa perdasaan dengan jumlah lahan yang masih luas, serta akses yang jauh dari fasilitas pengelolaan sampah pemerintah daerah (pemda). Perdesaan tidak terlalu merasakan persoalan sampah karena masih ada lahan untuk menimbun atau membakar sampah, banyak lahan kosong untuk membuang sampah, misalnya di sungai, tepi sawah, atau tanah kosong. Hal tersebut diperkuat oleh Sucipto, ${ }^{6}$ yang menyatakan di desa jumlah sampah masih sedikit dan jenisnya pun tidak bervariasi sehingga alam masih dapat mengatasinya.

Faktor-faktor yang memengaruhi permasalahan sampah di DIY diantaranya adalah perilaku sadar lingkungan dan masalah ekonomi (retribusi). Tingkat pengetahuan dan sikap masyarakat tentang pengelolaan sampah di daerah pedesaan kemungkinan masih rendah sehingga memengaruhi perilaku sadar lingkungan.

Perbandingan dapat dilakukan dengan hasil penelitian Dusun Pedukuhan Desa Sidokarto Godean Sleman Yogyakarta yang masyarakatnya $(54,5 \%)$ memiliki sikap yang tidak baik dalam mengolah sampah. Sampah dibakar sehingga mengakibatkan pencemaran lingkungan. ${ }^{11}$ Penelitian di Kecamatan Daha Selatan menyebutkan pula bahwa tingkat pendidikan dan pengetahuan berkorelasi positif dengan pengelolaan sampah rumah tangga. ${ }^{12}$

Seluruh wilayah kabupaten kota di DIY telah memiliki TPA. Kota Yogyakarta memiliki TPA Piyungan, Kulon Progo memiliki TPA Banyuroto, dan Gunung Kidul memuliki TPA Baleharjo. TPA disediakan sebagai sarana mengelola sampah. Ketersediaan TPA merupakan bukti tanggung jawab pemerintah untuk memberikan pelayanan publik. Walaupun begitu, tetap ada permasalahan yaitu tidak semua sampah dapat terangkut. Hal ini mungkin karena terbatasnya sarana-prasarana seperti TPS, truk sampah, dan jalan yang bisa dilalui.

Kendala penyediaan layanan publik di antaranya adalah infrastruktur, sumber daya, dan kerangka kelembagaan pelayanan publik. Meningkatkan pelayanan publik seringkali merupakan permasalahan manajemen dibandingkan masalah teknis atau keuangan. Permasalahan adanya TPA, yaitu daerah tersebut banyak mengalami pencemaran air, tanah, ataupun udara. Sampah yang dibuang ke TPA sebagian besar berasal dari wilayah perkotaan. Sampah perkotaan lebih banyak dalam volume dan kandungan bahan berbahaya yang berpotensi mencemari lingkungan sekitar TPA.

Lahan TPA semakin terbatas akibat penduduk sekitar menolak kehadiran TPA karena metode open dumping mengakibatkan pencemaran air permukaan dan air tanah (dari air lindi), udara (bau dan asap), serta tanah (sampah dan air lindi) dan menjadi sarang penyakit. ${ }^{13}$

Di TPA Piyungan banyak ditemukan bahan-bahan berbahaya yang dibuang seperti aki, batu baterai, serta pecahan lampu tubular lamps (TL) bekas. Bahan tersebut mengandung unsur timbal $(\mathrm{Pb})$ yang berbahaya bagi manusia. ${ }^{14}$ Sampah di TPA sebagian besar berasal dari sampah domestik, dan di dalamnya ada bahan berbahaya misalnya, seperti deterjen, pemutih, dan minyak pelumas. ${ }^{15}$

Penerapan program pengelolaan sampah yang diselenggarakan oleh pemda di Kabupaten Bantul, Sleman, Kulon Progo dan Gunung Kidul belum dapat mencakup seluruh wilayah. Program hanya dapat menjangkau di sekitar ibu kota kabupaten, hanya wilayah Kota Yogyakarta yang program pengelolaan sampah mandiri dapat menjangkau seluruh wilayah. Hal ini disebabkan oleh terbatasnya akses layanan, kesediaan SDM, dan luasnya wilayah. Daerah perkotaan menjadi prioritas utama dari program. Tidak semua desa atau kelompok dalam masyarakat terjangkau program pengelolaan sampah pemerintah. Keaktifan dari wilayah/kelompok masyarakat desa memegang peranan penting dalam keikutsertaan program.

Akses informasi pada tindakan dan kinerja pemerintah merupakan hal yang penting sebagai media promosi bagi akuntabilitas pemerintah. Akses merupakan salah satu komponen penting dalam keberhasilan partisipasi masyarakat. Masyarakat dengan akses informasi menjadi 
lebih mudah mengikuti kebijakan publik. ${ }^{16}$

Tantangan penerapan program pengelolaan sampah di daerah perkotaan adalah sifat masyarakat cenderung individual, bersifat ekonomis, dan sulit untuk menerima program baru. Masyarakat perkotaan cenderung bersifat kritis dan realistis sehingga dibutuhkan proses sosialisasi yang baik dan bekelanjutan. Masyarakat perkotaan harus diberi pemahaman tentang keuntungan, efektivitas, dan efisiensi dari program pengolahan sampah agar dapat berpartisipasi.

Tanpa adanya pemahaman kepada masyarakat, pengelolaan sampah akan sulit untuk diterapkan karena berbagai alasan di antaranya adalah sibuk, tidak ada waktu, dan banyak alasan yang lainnya. ${ }^{17}$ Sebagian besar pengelola kota/kawasan masih menggunakan cara berpikir desa yang menganggap alam masih dapat menangani permasalahan sampah dengan sendirinya. ${ }^{6}$ Keberlangsungan program pengelolaan sampah tergantung dari kesadaran masyarakat untuk bergerak. Tanpa kesepakatan pimpinan bersama masyarakat, kebijakan pengelolaan sampah tidak mungkin terlaksana. Kebijakan pengelolaan sampah akan berhasil apabila terdapat kepemimpinan yang baik, serta didukung penuh oleh pemuka masyarakat, visi, misi dan tujuan organisasi yang jelas.

Pengelolaan sampah bertujuan menciptakan lingkungan dan masyarakat yang sehat, maka faktor utama yang harus diperhatikan adalah peran serta masyarakat. Peran serta masyarakat merupakan aspek penting dalam melaksanakan pengelolaan sampah. Mengubah perilaku masyarakat merupakan hal yang cukup sulit, tetapi dengan pembinaan terus hasil akan diperoleh. ${ }^{12}$ Inisiator atau stimulator dibutuhkan dalam membentuk organisasi/kelompok. Memperkenalkan gagasan dan norma baru memerlukan kewibawaan tersendiri, untuk menjamin berhasilnya sesuatu kegiatan baru serta pembagian hak dan kewajiban yang adil. ${ }^{13}$ Organisasi membutuhkan seorang pemimpin dalam menjalankan kegiatannya.

Pemimpin yang baik akan dipatuhi anggotanya karena rasa hormat dan loyalitas bawahan, demikian pula pada organisasi sosial kemasyarakatan. Hal ini karena sifat kegiatannya merupakan sukarela, tidak bergaji, dan bersifat sosial. Kesediaan masyarakat perlu ditumbuhkan diantaranya dengan teladan dan motivasi dari pemimpin. Pemimpin dapat mengarahkan, memengaruhi, dan menetapkan pilihan terhadap suatu program. Program pengelolaan sampah mandiri yang diselenggarakan oleh pemerintah daerah tidak akan berhasil terlaksana apabila pemerintah tidak dapat melibatkan pemimpin masyarakat setempat.

Kemampuan memengaruhi dipandang sebagai modal utama bagi seseorang (pemimpin) untuk memperoleh kesan, rasa hormat, kepatuhan, loyalitas, dan kerja sama, serta menimbulkan harapan. Dengan kemampuan ini pula seseorang dapat mengubah kepercayaan, nilai-nilai, pendapat, sikap, dan perilaku orang lain. ${ }^{18}$

Walaupun pembuatan keputusan dilakukan bersama, pengaruh pemimpin seringkali masih sangat besar. Ketua dapat menyatakan pilihannya secara langsung (terbuka), bahkan mengarahkan anggotanya maupun secara tidak langsung, dan para 'pengikut setianya' akan mengikuti pilihan ketua serta seringkali secara kasat mata agar dapat dilihat oleh sang ketua. ${ }^{18}$

\section{Kebijakan Pengelolaan Sampah di Kabupaten/Kota DIY}

Dari Tabel 2 diperoleh hasil bahwa badan pelaksana untuk pengelolaan sampah tiap kabupaten dan kota memiliki perbedaan. Pada awalnya, permasalahan sampah di DIY memang dikelola oleh DPU yang memiliki sarana prasarana untuk pengelolaan sampah. Sejalan dengan perkembangan organisasi pada pemerintah dan hubungan sampah dengan lingkungan hidup, dibentuklah suatu badan yang dikhususkan untuk mengelola lingkungan. Pada prinsipnya, pengelolaan sampah perkotaan dapat dilakukan oleh unit atau badan apapun asalkan terdapat pembagian kerja, program, dan standar operasional prosedur (SOP) yang jelas. Hal yang terpenting adalah tujuan dari pengelolaan sampah tercapai.

Di Kota Yogyakarta dan Kabupaten Sleman, Bantul, Kulon Progo, dan Gunung Kidul juga menunjuk dinas tertentu untuk bertanggung jawab terhadap pengelolaan sampah. Hal tersebut sesuai dengan penelitian yang dilakukan di Kota Samarinda bahwa penanganan sampah domestik umumnya ditangani oleh pemerintah di tingkat provinsi maupun tingkat pemerintah kota/kabupaten. Untuk menangani sampah di Kota Samarinda, dibentuk Dinas Kebersihan dan Pertamanan. ${ }^{19}$

Regulasi sebagai dasar kegiatan pelayanan yang diberikan oleh pemerintah kepada masyarakat tentang pengelolaan sampah diwujudkan dalam bentuk peraturan perundangan di setiap kabupaten kota di DIY. Regulasi tersebut sebagai dasar hukum pelaksanaan kegiatan dan berperan sebagai aturan yang harus ditaati oleh masyarakat. Penegakan hukum (law enforcement) dikatakan sebagai salah satu upaya peningkatan partisipasi. Kesadaran masyarakat terhadap regulasi akan sangat membantu upaya pengelolaan sampah. ${ }^{19}$ Penegakan hukum menjadi salah satu pembangun budaya sadar lingkungan. Budaya tersebut diwujudkan dengan membuat peraturan perundangan (regulasi), pembatasan wilayah, dan pemberian kompensasi ekonomi berupa insetif dan disinsentif. 20

Reward atau insentif dalam penegakan hukum dibutuhkan. Insentif merupakan motivasi dan pendukung profesionalisme dalam bekerja. Hal tersebut perlu mendapatkan perhatian apabila menghendaki kerja yang optimal dari orang yang bekerja untuk perusahaan tersebut. 
Insentif dapat berupa penghargaan ataupun kompensasi sebagai balasan dalam melakukan sesuatu. 21

Tiap kota/kabupaten di DIY memiliki program-program untuk mengurangi volume sampah ke TPA dan merupakan pengelolaan sampah terpadu perkotaan. Proyek pengolahan sampah yang dilakukan oleh kabupaten/kota di DIY diterapkan dengan konsep tiga R (3R), yaitu reduce, reuse, recycling. Pengelolaan sampah terpadu dapat didefinisikan sebagai pemilihan dan penerapan teknikteknik, teknologi, dan program-program manajemen. ${ }^{22}$ Pengelolaan sampah terpadu perkotaan meliputi pengendalian timbulan sampah, pengumpulan sampah, transfer dan transport, pengolahan, dan pembuangan akhir. Pengelolaan limbah domestik harus dilakukan secara terpadu oleh semua pihak, pemerintah, masyarakat, lembaga swadaya masyarakat (LSM) dan perguruan tinggi. ${ }^{10}$ Konsep 3R merupakan konsep dasar pengelolaan sampah yang diterapkan di perkotaan, seperti pengolahan sampah di Kecamatan Klungkang Kebupaten Klungkang dan dilaksanakan di Kota Samarinda. ${ }^{19,22}$

\section{Dampak Perubahan Kualitas Lingkungan dan Masyarakat}

Perilaku bertanggung jawab terhadap lingkungan, dapat membantu menciptakan kebersihan lingkungan. Kebijakan pengelolaan sampah yang diterapkan di DIY diharapkan dapat mengubah perilaku masyarakat sehingga daya dukung lingkungan dapat terus dirasakan oleh masyarakat. Daya dukung lingkungan dipengaruhi oleh perilaku manusia.

Dampak dari kebijakan pengelolaan sampah salah satunya adalah terjaganya kebersihan lingkungan. Lingkungan yang bersih akan meningkatkan kesehatan masyarakat, meningkatkan kualitas hidup manusia, dan mendukung produktivitas manusia. Pernyataan tersebut sesuai dengan Sidar, ${ }^{3}$ bahwa mengelola sampah membantu meningkatkan perekonomian dan kebersihan lingkungan, serta menghindarkan dari berbagai penyakit.

Dampak pengelolaan sampah bagi komunitas dan pemerintah adalah meningkatkan kualitas lingkungan, perekonomian, sosial kemasyarakatan, dan budaya lingkungan. Pengalaman daerah dalam mengelola sampah di antaranya pengelolaan sampah terpadu di Kabupaten Sragen, Sukunan Bersemi di Banyuraden dan Sleman Yogyakarta, Tangerang (perumahan Mustika Tigaraksa). ${ }^{24}$

\section{Metode Pemantauan dan Evaluasi Kebijakan Pengelolaan Sampah}

Dari Tabel 3, dapat diketahui bahwa belum ada dokumen laporan pemantauan dan evaluasi kebijakan pengelolaan sampah. Akan tetapi, telah ada data-data yang secara periodik di-update untuk mengetahui kondisi persampahan di wilayah masing-masing dan ada beberapa dokumen lain yang merupakan dokumen pelaporan program kerja yang bersisi data dan cerita keberhasilan dan jalannya program tentang sampah.

Akuntabilitas dilaksanakan dengan cara penyusunan perencanaan strategis, pelaksanaan kegiatan, pengukuran kinerja, dan pelaporan. ${ }^{25}$ Akuntabilitas merupakan perwujudan kewajiban instansi pemerintah untuk mempertanggungjawabkan keberhasilan ataupun kegagalan pencapaian tujuan dan sasaran organisasi secara periodik. Dokumen seperti laporan atau profil tentang persampahan di kabupaten/kota DIY telah tersedia dan wajib dibuat oleh pemda unit khusus masalah persampahan.

Monitoring dan evaluasi dibutuhkan dalam kegiatan pengelolaan sampah. Hal tersebut berkaitan dengan keberlangsungan program. Apabila pemerintah melalui dinas terkait terbatas untuk melakukan monitoring dan evaluasi. Pemerintah dapat menggunakan perpanjangan tangan dari pemerintah desa ataupun perangkan desa yang lain, bahkan dapat menggandeng organisasi sosial ataupun organisasi masyarakat.

Sistem monitoring dan evaluasi yang dilaksanakan di Kota Samarida dapat menjadi contoh. Penanganan sampah diperlukan pengawasan yang terus-menerus dan dievaluasi terus-menerus, antara lain pengawasan secara intern di dalam rumah tangga ketua RT di wilayahnya dengan pengawasan secara langsung, insfeksi rutin oleh lurah, dan dinas keberhasilan mengawasi para petugas kebersihan dengan membentuk koordinator lapangan. ${ }^{19}$

\section{Kesimpulan}

Persamaan dalam pengelolaan sampah di lima kabupaten/kota di DIY adalah kebijakan yang diterapkan di setiap wilayah bervariasi dasar hukumnya. Akan tetapi, telah ada badan/unit yang bertanggung jawab mengelola sampah dengan berbagai program dan projek yang dijalankan sebagai bentuk pelayanan publik di DIY sesuai dengan ketentuan undang-undang persampahan. Perubahan akibat pengelolaan sampah adalah lingkungan menjadi bersih, asri, dan nyaman, serta mendatangkan manfaat ekonomi. Metode pemantauan dan evaluasi kebijakan pengelolaan sampah di DIY memiliki persamaan di lima kabupaten/kota, yaitu belum dituangkan dalam prosedur baku tetapi telah memenuhi tanggung jawabnya dalam akuntabilitas dan transparansi pelayanan publik.

\section{Saran}

Kebijakan pengelolaan sampah di perkotaan dengan melibatkan masyarakat, badan usaha, atau instansi pemerintah lain perlu dilakukan di daerah sehingga permasalahan sampah dapat dicegah. Kebijakan akan berjalan dengan optimal ketika ada mekanisme monitoring dan evaluasi yang baik dari pihak pemerintah daerah di DIY.

\section{Daftar Pustaka}

1. Sudradjat HR. Mengelola sampah kota. Jakarta; Penerbit Penebar 
Swadaya; 2006.

2. Tim Penulis Penebar Swadaya. Penanganan dan pengolahan sampah. Jakarta: Penerbit Penebar Swadaya; 2008.

3. Basriyanta. Memanen sampah. Yogyakarta: Penerbit Kanisius; 2011.

4. Tim Penulis Redaksi Rumah. Pengelolaan sampah rumah tangga. Jakarta: Penerbit PT Prima Infosarana Media; 2008.

5. Annihayah. Urgensi manajemen persampahan ; belajar dari kasus Kota Bandung [online]. Bantul: Pemerintah Kabupaten Bantul; 2004 [Diakses 29 Juni 2006]. Diunduh dalam: http://www.bantul.go.id/web.php? mod=bantulkita\&baca $=31$

6. Sucipto CD. Teknologi pengolahan daur ulang sampah. Yogyakarta: Penerbit Gosyen Publ; 2012.

7. Badan Pengendalian Lingkungan Hidup DKI Jakarta. Pedoman pemberdayaan masyarakat dalam mengelola sampah. Jakarta: Terbitan Badan Pengendalian Lingkungan Hidup DKI Jakarta dan URDI; 2013.

8. Sarbidi. Kajian regionalisasi tempat pemrosesan akhir (TPA) sampah menggunakan analisis SWOT (Studi Kasus TPA Benowo Surabaya). Jurnal Pemukiman. 2009; 4 (1): 10-28.

9. Muttaqien AR, Sugiyantoro. Indentifikasi pengelolaan sampah kota Bandung (studi kasus Komplek Berung Indah, Komplek Perumahan Cibangkong, RW 8 Kelurahan Ciroyom, RW 02 Kelurahan Sukabungah, RW 02 Kelurahan Bina Harapan Cisaranten, dan Kelurahan Maleer). Jurnal Perencanaan Wilayah dan Kota. 2014; 1 (2): 354-62.

10. Yin RK. Studi kasus desain dan metode. Jakarta; PT RajaGrafindo Persada; 2004

11. Mulasari SA. Hubungan tingkat pengetahuan dan sikap terhadap perilaku asyarakat dalam mengelola sampah di Dusun Padukuhan Desa Sidokarto Kecamatan Godean Kabupaten Sleman Yogyakarta. Jurnal Kemas. Fakultas Kesehatan Masyarakat UAD. 2012; 6 (3): 204-11.

12. Riswan, Sunoko HR, Hadiyarto A. Pengelolaan sampah rumah tangga di Kecamatan Daha Selatan. Jurnal Ilmu Lingkungan. April 2011; 9 (1) : 31-9.

13. Sudarwanto S. Peran strategis perempuan dalam pengelolaan limbah padat bernilai ekonomi. Jurnal EKOSAINS. 2010 Maret; 2 (1): 65-74.

14. Ganefeti SP, Susanto JP, Suwarni A. Pengelolaan leachete tercemar Pb sebagai upaya pencegahan pencemaran lingkungan TPA. Jurnal Teknik
Lingkungan. 2008; 9 (1): 92-7.

15. Sangodoyin AY. Hazardous wastes assessing the efficacy of structures and approaches to management in Nigeria. Environmental Management and Health. 2000; 11 (1): 39-46.

16. Azfar O, Kähkönen S, Lanyi A, Meagher P, Rutherford D. Decentralization, governance and public services the impact of institutional arrangements. IRIS Center, University of Maryland, College Park; 1999.

17. Mulasari SA. The community participation factor of waste self management in Gondolayu Village Province of Yogyakarta. Proceeding International Seminar on Research in Sciences UAD. 2007.

18. Slamet JS. Kesehatan lingkungan. Yogyakarta: Gadjah Mada University Press; 2004.

19. Sudiran FI. Instrumen sosial masyarakat Karangmumus Kota Samarinda dalam penanganan sampah domestik. MAKARA, SOSIAL HUMANIORA. Juni 2005; 9 (1): 16-26.

20. Perdue WC, Stone LA, Gostin LO. The built enviroment and its relationship to the public's health : the legal framework. American Journal of Public Health. 2003; 93 (9): 1390-4.

21. Kingma M. Economic incentive in community nursing: attraction, rejection, or indifference. Human Resources for Health [seriasl on internet]. 2003 [cited 2013 Sept 4]; 1 (2). Available from: http://www.human-resources-health.com./content/1/1/2.

22. Yasa MT, Surayasa N. Studi evaluasi pengelolaan sampah dengan konsep 3R (studi kasus: Kecamatan Klungkung Kabupaten Klungkung). Jurnal Lingkungan. Februari 2012; 21 (1): 1-5.

23. Wibowo A, Djajawinata DT. Penanganan sampah perkotaan terpadu. 2002 [diakses 24 Mei 2006]. Diunduh dalam: http://kkpl.go.id/papbook/ penanganan $\% 20$ sampah\%20perkotaan $\% 20$ terpadu. pdf.

24. Sidarto. Analisis usaha proses pengelolaan sampah rumah tangga dengan pendekatan cost and benefit ratio guna menunjang kebersihan lingkungan. Jurnal Teknologi. Desember 2010; 3 (2): 161-8.

25. Ciptorini D, Hasanbasri M. Otonomi daerah dan akuntabilitas kinerja dinas Kesehatan Kabupaten Kulonprogo di Daerah Istimewa Yogyakarta. Jurnal Manajemen Pelayanan Kesehatan. Desember 2004; 7 (4): 211-7. 